\title{
Urban wastewater reuse: water treatment and effectiveness on antibiotic-resistant bacteria abatement
}

\author{
G. Del Re ${ }^{1}$, A. Di Donato ${ }^{1}$, R. Volpe ${ }^{1}$ \& M. G. Perilli ${ }^{2}$ \\ ${ }^{I}$ Department of Chemistry, Chemical Engineering and Materials, \\ L'Aquila University, Italy \\ ${ }^{2}$ Department of Biomedical Sciences and Technologies, \\ L'Aquila University, Italy
}

\begin{abstract}
In Abruzzo Region (Italy) the implementation of European Community and National regulations for urban wastewater reuse has been carried out since 2003, when the Environmental National Authority issued the D.M. 185 giving technical rules and water quality standards for three types of reuse: irrigation, civil aims and industry. Pilot plant experiences of tertiary treatments added to conventional urban wastewater treatment plants (UWWTPs) have been carried out, in order to test the suitability of different disinfection technologies to reach the standards required for an effluent to be reused. In addition other parameters affecting the quality of reclaimed water, and for which there is currently no regulation or control, have been investigated; among them, antibiotic resistant bacteria concentration. To evaluate the extent of problems related to antibiotic resistant bacteria and the effectiveness of tertiary treatment on their abatement level, a significant portion of the wastewater network of the city of L'Aquila (Italy) and the related wastewater treatment plant were monitored. Antibiotic resistant bacteria content in non-treated sewage from municipal hospital and residential areas was evaluated. The UWWTP treating this sewage is of activated sludge type and is located near the Aterno River. The wastewater coming from the secondary treatment and from the tertiary treatments was analysed in order to investigate the influence on the antibiotic-resistant bacteria content. An analogous investigation was carried out in the river upstream and downstream the point of discharge of the UWWTP.
\end{abstract}

Keywords: wastewater treatment, water reuse, antibiotic-resistant bacteria. 


\section{Introduction}

Water treatment matters are never obsolete and continuously evolving. One of the most recent concerns is about wastewater reuse. Water reuse practice is a viable and effective sustainable development policy application, meaning significant reduction of water sources withdrawals and, on the other hand, corresponding increase of potable water availability. In particular, urban wastewater reuse should allow the saving of a great part of the whole water consumption in the developed world if it would become a common practice and not only a contingent solution for drought situations. However, care must be paid on microbiological safety of reclaimed water, even for the aspects not yet considered by both national and international regulations but involving matters of potential risks for human health; one of them, investigated in this work, is the presence of antibiotic-resistant bacteria in wastewater distribution network.

Italian Government established a regulation on water reuse which consists of decree "D.M. n.185/2003", issued by the National Environmental Authority (Ministero dell'Ambiente) complying with Article 26 of the Italian Unified Body of Laws for protection of waters, the Decree n. 152/1999. Decree n.152/1999 implements the European Directives "Urban Waste Water Treatment - Directive 91/271/EEC" and "Protection of waters against pollution caused by nitrates from agricultural sources - Directive 91/676/EEC".

As reported in detail elsewhere [1], D.M. n.185/2003 establishes the quality standards and technical rules for urban wastewater reuse for three reuse categories: irrigation, industrial and civil. D.M. n.185/2003 establishes that regional Authorities must individuate a first set of urban wastewater treatment plants (UWWTPs) whose effluents have to be reused. Such plants are those one whose effluents, in the current configuration, have only few parameters exceeding the limits established for water reuse, allowing to meet the standards for water reuse with affordable investments for plant modifications. Regional Authorities have also to choose, among the suitable best available technologies, the additional treatments needed to meet the quality standards for water reuse and they have to indicate, for each UWWTP, the most convenient types of reuse, suggested by an accurate analysis of the plant surrounding area. Wastewater reclamation in agriculture appears to be a key topic, especially in Southern Italian regions [2]. The quality standards for water reuse established by D.M. $185 / 2003$ are very stringent, in comparison to the water quality indicated by the regulation for protection of surface waters (Decree n.152/1999), especially for parameters such as total suspended solids (TSS), microbial pollution indicators (fecal coliform Escherichia Coli, EC) or heavy metals; moreover, it introduces parameters not considered in the emission limits for urban wastewater plants, such as total trihalomethanes (TTHM) and chlorinated pesticides.

Most of the UWWTPs in operation in the Abruzzo Region are of activated sludge or rotating biodisc type. When they are properly designed and operated their effluents have negligible heavy metal concentrations, and the only parameters which do not comply with the standards for water reuse are TSS and $\mathrm{EC}$; consequently, in order to meet the standards for water reuse, UWWTPs have 
to be modified including a proper filtration section for TSS reduction and a disinfection process (for EC reduction) based on technology alternative to chlorine disinfection. The chlorine concentration to be used to meet the stringent limits on microbiological parameters is incompatible with the chlorine residuals. In addition, when using chlorine, harmful chloro-organic by products can be formed.

The best disinfection technologies alternative to chlorine disinfection commercially available are based on the use of UV, ozone and microfiltration $[3,4]$; Peracetic Acid (PAA) has been proposed for wastewater disinfection treatments, but its behaviour is still under assessment $[5,6]$. Its use has some drawbacks, such as the increase of organic content in the treated effluent, the potential microbial re-growth due to the residual acetic acid, the limited efficiency against viruses and parasites and the strong dependence on wastewater quality [7].

Some water reuse projects are in operation in Europe: Bixio et al [8], have identified about 200 reuse projects, most of them of small $\left(0,1-0,5 \mathrm{Mm}^{3} / \mathrm{y}\right)$ or medium size $\left(0,5-5 \mathrm{Mm}^{3} / \mathrm{y}\right)$. The experiences of the different projects are not directly comparable, as they are based on different technologies, are intended for different uses and refer to different water reuse criteria.

The lack of a systematic and properly managed experience of wastewater reuse and, consequently, the lack of reliable data asserting the effectiveness of the different filtration and disinfection treatments to meet the enforced target indicators, the reasonable doubts expressed by the scientific community on the exhaustive character of the enforced laws in the limitation of the risk involved in wastewater reuse practice [9-12] make local authorities and water management stakeholders to urge researchers and technicians to conduct suitable experimental works at pilot plant scale before initializing any massive intervention.

An experimental campaign was conducted on a municipal biodisc WWTP serving a community of 7,000 P.E.; the effluent was treated in a tertiary treatment pilot plant (TTPP) consisting of rotary filtration (RF) and UV disinfection.

In addition, an investigation of the presence of antibiotic-resistant bacteria at the inlet and outlets of the TTPP and at different locations of a 28,000 P.E. activated sludge UWWTP were carried out, as presented in the following paragraphs. Antibiotic-resistant bacteria collected from and disposed on environment and travelling through the whole wastewater treatment network is an urgent, and perhaps underestimated, problem of the $21^{\text {st }}$ century [13-19].

\section{Experimental}

This work presents the results of two experiences of water treatment monitoring in which an antibiotic bacteria presence investigation has been carried out.

The first experience deals with a typical domestic wastewater treatment plant in which a tertiary pilot scale plant, consisting of rotary filtration followed by UV disinfection, was added and its effectiveness on antibiotic-resistant bacteria 
abatement was compared with the performances of the existent tertiary treatment, i.e. chlorination.

The second experience reports the preliminary results of antibiotic-resistance investigation in a network collecting and treating sewage of different origins, not only typical domestic as in the first case: wastewater from hospitals, universities, houses and small-medium farms are collected, then treated in an activated sludge plant and disposed in a river.

Paragraphs 2.1 and 2.2 report sampling locations and analysis methods for the two experiences, respectively; paragraphs 3.1 and 3.2 report the corresponding results and discussion.

\subsection{Pilot plant experience}

The schematic diagram of the biodisc UWWTP plant is shown in Figure 1, together with the added tertiary treatment pilot plant (TTPP). The plant serves a community of about 7,000 P.E., no significant industrial activities are present in the served area, so the waste water treated by the plant is substantially domestic water.
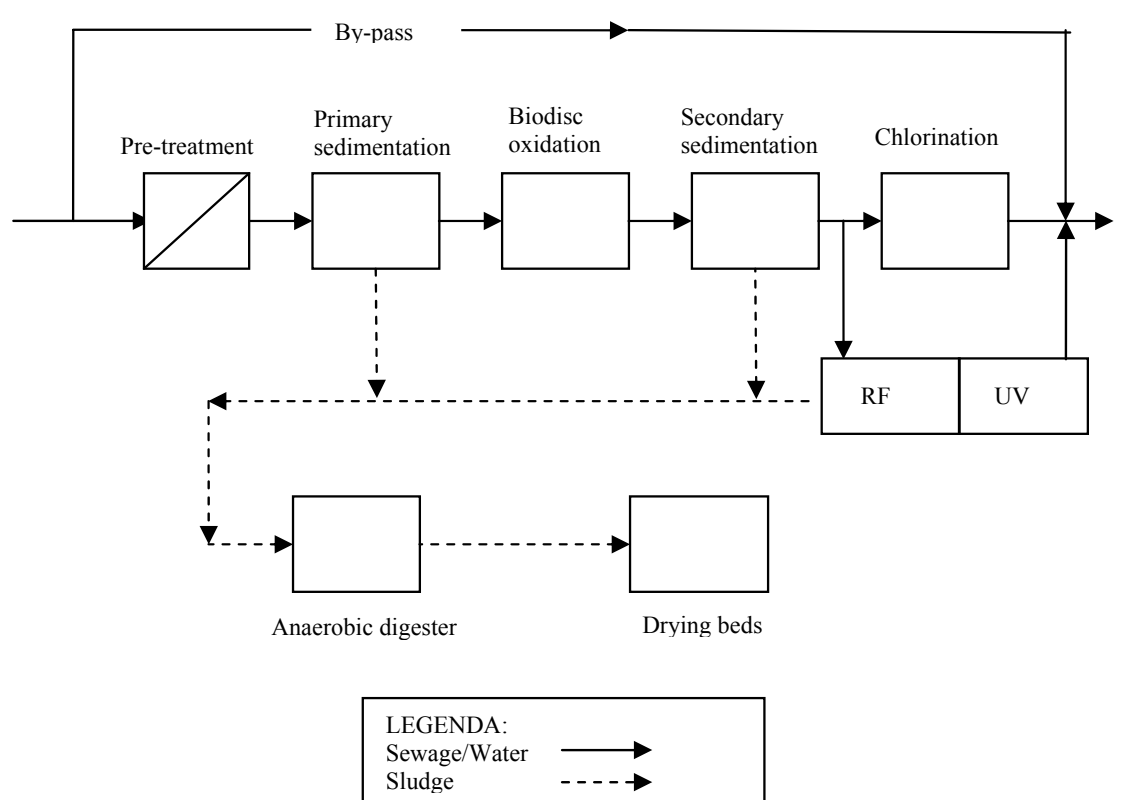

Figure 1: $\quad$ UWWTP schematic diagram, with the TTPP (RF+UV) section.

The TTPP was designed to treat a flow-rate of about $7 \mathrm{~m}^{3} / \mathrm{h}$, but different flow rates have been used during the experience in order to test the effect of different UV doses and to evaluate the operative conditions that allow one to best attain the water quality targets. 
The period of the experience was of 14 weeks, from spring to summer, with an average water temperature at UWWTP output of about $15^{\circ} \mathrm{C}$.

The main objective of the work, as reported in [20], was to evaluate performances and reliability of a tertiary treatment of a municipal WWTP effluent, in order to meet the quality standards for water reuse.

In this work we want to focus on the investigation of the presence of antibiotic-resistant bacteria at the inlet and outlets of the TTPP.

Six $250 \mathrm{ml}$ samples were collected from the influent and effluent of the TTPP, distributed over the experience period. All samples were collected in sterile propylene bottles and transported to the laboratory for immediate processing. $1 \mathrm{ml}$ from every sample was diluted with physiological sterile $\mathrm{NaCl}$ solution $(0,9 \mathrm{~g} / \mathrm{l} \mathrm{NaCl}) .100 \mu \mathrm{l}$ volume from each dilution was then plated on a Nutrient Agar culture medium. The plates were incubated for $24 \mathrm{~h}, 48 \mathrm{~h}$ and $72 \mathrm{~h}$ at $37^{\circ} \mathrm{C}$ for the determination of the bacterial counts and converted on $\mathrm{CFU} / \mathrm{ml}$. In order to obtain isolated colonies for preliminary identification, dilutions of each sample were plated on selective medium. The agar plates were incubated for $24 \mathrm{~h}$ at $37^{\circ} \mathrm{C}$. For pure cultures, a representative for each different colony morphology was re-isolated on clear plates and incubated for $24 \mathrm{~h}$ at $37^{\circ} \mathrm{C}$. The Enterotube (Becton Dickinson), API-20E (Biomerieux) and API20NE (Biomerieux) systems were used for the preliminary identification of some gram-negative isolates. All isolated strains were identified by Phoenix system (Becton Dickinson).

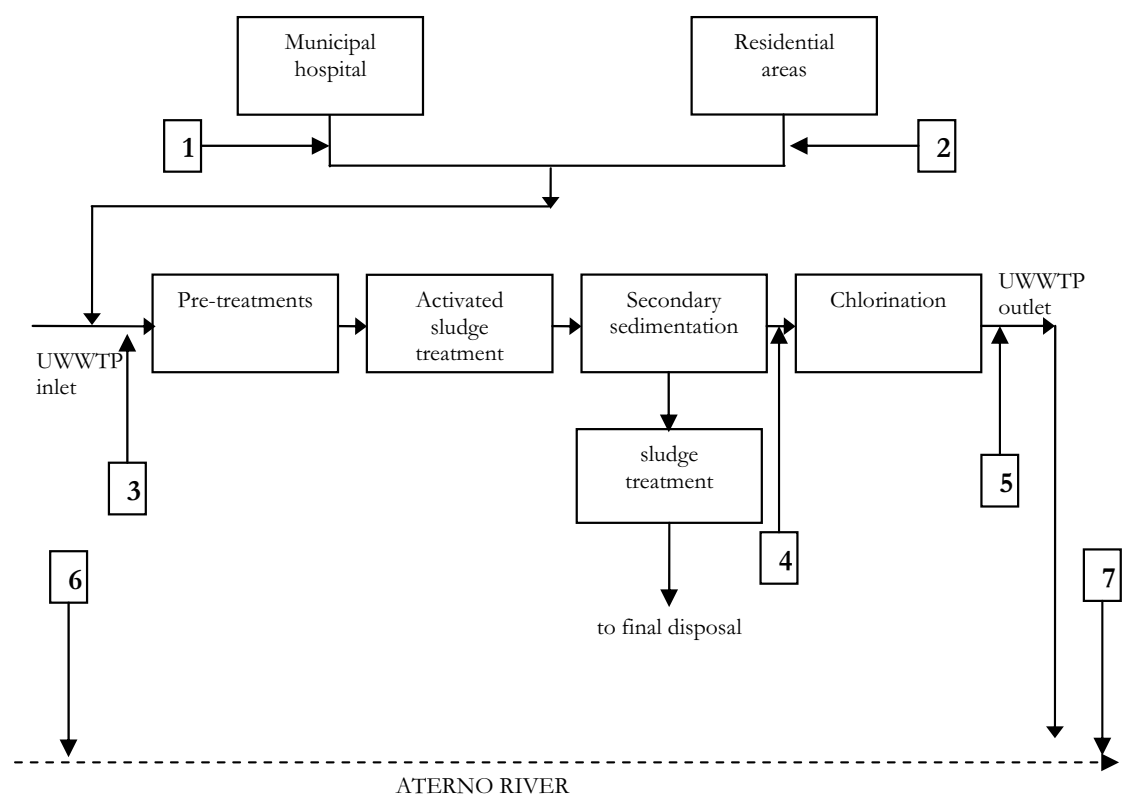

Figure 2: Wastewater network monitoring scheme. 


\subsection{Wastewater network monitoring}

It was scheduled to monitor the antibiotic-resistant bacteria presence by sampling wastewater in different locations, as shown in Figure 2: non-treated sewage from municipal hospital (Sampling Location 1) and residential areas (SL 2); UWWTP inlet (SL 3); secondary treatment outlet (SL 4) and tertiary treatment outlet (SL 5); in the river upstream (SL 6) and downstream (SL 7) the point of discharge of the UWWTP.

Sampling frequency was about once a month. The work is still in progress; in this work we report the preliminary results for the first six sampling series, obtained from June 2006 to January 2007.

Samples have been collected and analysed for total bacterial count in the same way as reported for the first experience. The isolates identification in this case has been carried out using Imipenem $2 \mu \mathrm{g} / \mathrm{ml}$ and Ceftadizime $4 \mu \mathrm{g} / \mathrm{ml}$, i.e. two of the most effective antibiotics used nowadays.

Table 1: Total number of strains selected in this study.

\begin{tabular}{|c|c|c|c|}
\hline \multirow[t]{2}{*}{ Strains } & $\begin{array}{l}\text { Total Number } \\
\text { of Strains }\end{array}$ & $\begin{array}{l}\text { N. of strains } \\
\text { after UV }\end{array}$ & $\begin{array}{l}\text { N. of strains after } \\
\text { chlorination }\end{array}$ \\
\hline & & $(\%)$ & $(\%)$ \\
\hline Achromobacter spp. & 2 & 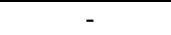 & - \\
\hline Acinetobacter lowffii & 4 & $3(75 \%)$ & $1(25 \%)$ \\
\hline Aereomonas caviae & 18 & $2(11 \%)$ & $5(28 \%)$ \\
\hline Aereomonas hydrophila & 3 & $1(33.3 \%)$ & - \\
\hline Aereomonas sobriae & 7 & $2(28 \%)$ & $1(14.2 \%)$ \\
\hline Aereomonas veronii & 1 & $1(100 \%)$ & - \\
\hline Alcaligenes faecalis & 1 & - & - \\
\hline Citrobacter braaki & 1 & - & $1(100 \%)$ \\
\hline Citrobacter farmeri & 1 & - & - \\
\hline Citrobacter freundii & 7 & - & $7(100 \%)$ \\
\hline Citrobacter werkmanii & 1 & - & - \\
\hline Citrobacter youngae & 1 & - & $1(100 \%)$ \\
\hline Comamonas testosteroni & 2 & $1(50 \%)$ & - \\
\hline Delfia acidovorans & 2 & $2(100 \%)$ & - \\
\hline Enterobacter asburiae & 1 & - & - \\
\hline Enterobacter cloacae & 4 & - & $4(100 \%)$ \\
\hline Enterobacter intermedius & 2 & - & $2(100 \%)$ \\
\hline Escherichia coli & 17 & $2(11.7 \%)$ & $10(58.8)$ \\
\hline Escherichia vulneris & 1 & - & $1(100 \%)$ \\
\hline Klebsiella oxytoca & 7 & - & $3(42.8)$ \\
\hline Klebsiella pneumoniae & 3 & - & $3(100 \%)$ \\
\hline Kluyvera ascorbata & 1 & - & $1(100 \%)$ \\
\hline Mannheimia haemolytica & 1 & - & $1(100 \%)$ \\
\hline Morganella morganii & 1 & - & - \\
\hline Pantoea agglomerans & 1 & - & - \\
\hline Providencia rettgeri & 1 & - & - \\
\hline Pseudomonas aeruginosa & 1 & - & - \\
\hline Pseudomonas mendocina & 2 & - & $2(100 \%)$ \\
\hline Pseudomonas putida & 2 & - & $1(50 \%)$ \\
\hline Pseudomonas species & 2 & - & $2(100 \%)$ \\
\hline Shigella boydii & 1 & - & - \\
\hline Tatumella ptyseos & 1 & - & - \\
\hline Total & 100 & $14 \%$ & $46 \%$ \\
\hline
\end{tabular}




\section{Results and discussion}

\subsection{Pilot plant results}

When microorganisms were growth on the selective medium 100 different strains belonging to the several species were identified. The most common organism detected was Aeromonas cavie (18 strains) followed by E. coli (17 strains) and Klebsiella oxytoca (7 strains). The other species were represented only by few isolates.

As shown in Table 1 after UV treatment only $14 \%$ of total strains were detected whereas $46 \%$ of strains were detected after chlorination treatment.

Some bacterial species were completely destroyed by both treatments. In particular Enterobacter spp, Klebsielle spp., Pseudomonas spp and Citrobacter freundii strains were eliminated only after UV treatment, whereas Aeromonas hydrophila, Aeromonas veronii, Comomonas testosteronii and Delfia spp. were destroyed only by chlorination treatment. The phenotypic profile of all 100 strains collected was carried out by minimal inhibitory concentration experiments using B-lactam antibiotics and an inoculum of $10^{5} \mathrm{CFU} / \mathrm{ml}$. Citrobacter spp., E. coli, Klebsiella spp., Aeromonas spp. and Pseudomonas spp. strains showed an evident resistance phenotype toward penicillins and cephalosporins tested. In particular several bacterial were resistant to oxyiminocephalosporins such as cefotaxime and ceftazidime. The resistance toward these two ß-lactams were typical of Extended Spectrum ß-Lactames (ESßL)-producing strains that represents an emergent problem in hospitals and communities.

\subsection{Wastewater network monitoring results}

The waste waters and sampling locations were chosen so as to identify the sources of antibiotic-resistant bacteria and their potential abatement in a waste water treatment plant. Another key point is the distinction between clinical and environmental isolates in the different samples.

Table 2 reports the types of strains identified in each sampling location. Looking at the results reported in Table 2, some apparent inconsistencies can be noticed: Klebsiella pneumoniae that has been detected in SL5 (downstream the chlorination treatment) and in SL7, has not been detected in the sampling locations upstream the chlorination treatment. This is due to the difficulty in isolating the different colonies when the total bacteria count is very high, as it happens upstream the disinfection section.

On the other hand, a significant results is that the strains found in SL 5, i.e. after the tertiary treatment of chlorination, are the minimum number of strains found all over the network investigated; this shows the effectiveness of the chlorination. Anyway, even after chlorination, some clinical isolates, such as Criseobacterium meningosepticum also found in SL1, are still present. The incomplete abatement of antibiotic resistant bacteria, especially when they are represented by clinical isolates, is obviously a potential risk for human health. 
Also a sample of sludge from the waste water treatment plant was analyzed and antibiotic resistant bacteria were found. As often sludge is used for compost production, attention should be paid to this aspect to avoid contamination of food chain.

Table 2: $\quad$ Strains identified in each sampling location and number of isolates.

\begin{tabular}{|c|c|c|c|}
\hline SL & STRAIN & SL & STRAIN \\
\hline \multirow{8}{*}{1} & Pseudomonas pseudomallei: 2 & \multirow{5}{*}{4} & Citrobacter freundii: 1 \\
\hline & Enterobacter agglomerans: 3 & & Enterobacter spp.: 2 \\
\hline & Pseudomonas putida: 2 & & Stenotrophomonas maltophilia: 3 \\
\hline & Stenotrophomonas maltophilia: 3 & & Klebsiella oxytoca: 1 \\
\hline & $\begin{array}{l}\text { Criseobacterium } \\
\text { meningosepticum/indologenes: } 1\end{array}$ & & A.idroph./vibrio fluvialis: 2 \\
\hline & Areomonas hydrophila: 4 & \multirow{3}{*}{5} & E.coli: 1 \\
\hline & Citrobacter freundii: 2 & & Klebsiella pneumoniae: 1 \\
\hline & Klebsiella oxytoca: 2 & & Criseobacterium meningosepticum: 1 \\
\hline \multirow{6}{*}{2} & Areomonas hydrophila: 2 & \multirow{2}{*}{6} & Areomonas hydrophila: 3 \\
\hline & Pseudomonas spp.: 3 & & Klebsiella oxytoca: 1 \\
\hline & Enterobacter agglomerans: 2 & \multirow{4}{*}{7} & Klebsiella pneumoniae: 1 \\
\hline & Stenotrophomonas maltophilia: 4 & & Areomonas hydrophila: 2 \\
\hline & Kluyvera spp: 1 & & Erwinia spp.: 1 \\
\hline & Vibro fluvialis: 2 & & E. coli: 2 \\
\hline \multirow{10}{*}{3} & A.idroph./vibrio fluvialis: 1 & & \\
\hline & Vibrio vulnificus: 1 & & \\
\hline & Enterobacter cloacae: 2 & \multirow{8}{*}{$\begin{array}{c}\text { Dried } \\
\text { sludge }\end{array}$} & \\
\hline & Areomonas hydrophila: 3 & & Areomonas hydrophila: 2 \\
\hline & Crisiobacterium meningosepticum: 1 & & Enterobacter sakazakii: 1 \\
\hline & Areomonas spp: 4 & & \\
\hline & Acinetobacter spp.: 2 & & \\
\hline & Citrobacter freundii: 1 & & \\
\hline & Stenotrophomonas maltophilia: 2 & & \\
\hline & Salmonella spp: 1 & & \\
\hline
\end{tabular}

\section{Conclusions}

It has been evidenced that even in domestic waste waters various antibiotic resistant bacteria are present in relevant concentration. It has been shown that chlorination and UV have different effectiveness on the abatement of different antibiotic resistant bacteria strains, as they show different sensitivity to chlorination and UV, the latter giving the best results.

The preliminary results obtained in the wastewater network monitoring have confirmed the presence of antibiotic resistant bacteria in urban waste waters. In addition waste waters from a municipal hospital and mixed waste waters of different origin have been characterized, finding both clinical and environmental isolates.

Even if the enforced law does not consider the presence of antibiotic resistant bacteria in defining the parameters for water reuse, they are a key factor that should be taken into account for water quality assessment. 


\section{References}

[1] Caputi, P., Del Re, G., Di Donato, A., Petrongolo, A., Volpe R., Urban wastewater re-use in the Abruzzo region, WIT Transactions on Ecology and the Environment, Vol. 80, WIT Press, Conference Proceedings, pp. 455-464, 2005.

[2] Bonomo, L., Nurizzo, C., Rolle, E., Advanced wastewater treatment and reuse: related problems and perspectives in Italy, Wat. Sci. Tech., Vol.40. No. 4-5, pp. 21-28, 1999.

[3] Liberti, L., Notarnicola, M., Advanced treatment and disinfection for municipal wastewater reuse in agriculture, Wat. Sci. Tech. Vol.40, No. 45, pp.235-245, 1999.

[4] Urkiaga, A., Best available technologies for water reuse and recycling: needed steps to obtain the general implementation of water reuse, 9th European Roundtable on Sustainable Consumption and Production (ERSCP), Bilbao, Spain, 2004.

[5] Dell'Erba, A., Falsanisi, D., Liberti, L., Notarnicola, M., Santoro, D., Disinfecting behaviour of peracetic acid for municipal wastewater reuse, Desalination, Vol. 168, pp. 435-442, 2004.

[6] Nurizzo, C., Antonelli, M., Profaizer, M., Romele, L., By-products in surface and reclaimed water disinfected with various agents, Desalination, Vol. 176, pp. 241-253, 2005.

[7] Baldry, M.G.C., Fraser, J.A.L., Disinfection with peroxygens, Critical Reports in Applied Chemistry, K.R. Payne ed., Vol.23, John Wiley \& Sons, Chichester, pp 91-116, 1988.

[8] Bixio, D., Thoeye, C., De Koning, J., Joksimovic, D., Savic, D., Wintgens, T., Melin, T., Wastewater reuse in Europe, Desalination, Vol. 187, pp. 89-101, 2006.

[9] Asano, T., Cotruvo, J.A., Groundwater recharge with reclaimed municipal wastewater: health and regulatory considerations, Water Research, Vol. 38, pp. 1941-1951, 2004.

[10] Nurizzo, C., Reclaimed water reuse in the Mediterranean region: some considerations on water resources, standard and bacterial re-growth phenomena, Wat. Sci. Tech.: Water Supply, Vol.3, No.4, pp. 317-324, 2003.

[11] Nwachuku, N., Gerba, C.P., Microbial risk assessment: don't forget the children, Current Opinion in Microbiology, Vol.7, pp. 206-209, 2004.

[12] Reinthaler, F.F., Posch, J., Feierl, G., Wüst, G., Haas, D., Ruckenbauer, G., Mascher, F., Marth, E., Antibiotic resistance of E.Coli in sewage and sludge, Water Research, Vol. 37, pp.1685-1690, 2003.

[13] Brookes, J. D., Antenucci, J., Hipsey, M., Burch, M. D., Ashbolt, M. J., Ferguson, C., Fate and transport of pathogens in lakes and reservoirs, Environment International, Vol. 30, pp. 741-759, 2004.

[14] Koivunen, J., Siitonen, A., Heinonen-Tanski, H., Elimination of enteric bacteria in biological-chemical wastewater treatment and tertiary filtration units, Water Research, Vol. 37, pp. 690-698, 2003. 
[15] Koren, H. S., Crawford-Brown, T., A framework for the integration of ecosystem and human health in public policy: two case studies with infectious agents, Environmental Research, Vol. 95, pp. 92-105, 2004.

[16] Kümmerer, K., Drugs in the environment: emission of drugs, diagnostic aids and disinfectants into wastewater by hospitals in relation to other sources - a review, Chemosphere, Vol. 45, pp. 957-969, 2001.

[17] Kümmerer, K., Alexy, R., Hüttig, J., Schöll, A., Standardized tests fail to assess the effects of antibiotics on environmental bacteria, Water Research, Vol. 38, pp. 2111-2116, 2004.

[18] Reinthaler, F.F., Posch, J., Feierl, G., Wüst, G., Haas, D., Ruckenbauer, G., Mascher, F., Marth, E., Antibiotic resistance of E.Coli in sewage and sludge, Water Research, Vol. 37, pp.1685-1690, 2003.

[19] Sanderson, H., Johnson, D. J., Reitsma, T., Brain, R. A., Wilson, C. J., Solomon, K. R., Ranking and prioritization of environmental risks of pharmaceuticals in surface waters, Regulatory Toxicology and Pharmacology, Vol. 39, pp. 158-183, 2004.

[20] Del Re, G., Di Donato, A., Volpe, R. and Pellegrini, C., Urban wastewater reuse: a pilot plant experience, Int. J. Environmental Technology and Management, in press. 